[Agr. Biol. Chem., Vol. 25, No. 1, p. 50 54, 1961]

\title{
Studies on the Chitinolytic Enzymes of Black-koji Mold
}

\author{
Part I. Viscometric Determination of Chitinase Activity by \\ Application of Glycol Chitin as a New Substrate
}

\author{
By Akira Ōtakara \\ Hiroshima Women's Jr. College*
}

Received July 26, 1960

\begin{abstract}
It has been found that glycol chitin is a suitable substrate for the viscometric determination of chitinase activity, because the viscosity of its aqueous solution is not affected by the presence of added salt and the changes of $\mathrm{pH}$, differing from chitosan acetate and carboxymethyl chitin used by earlier workers. Using this substrate the viscometric activity is determined, basing on the observation that the time required to halve the viscosity of reaction mixture is inversely proportional to the amount of enzyme used.
\end{abstract}

In earlier studies on chitinase, the activity has been determined by viscometric method, turbidometric method or the estimation of $\mathrm{N}$-acetylglucosamine or reducing sugar using the following substrates; native chitin, regenerated chitin, chitodextrin or chitosan. Generally, it seems most simple and sensitive to measure a rapid reduction in the viscosity of substrate solution, probably due to depolymerization, for the determination of activity in many studies of mucopolysaccharases. McClean \& Hale ${ }^{1)}$ and Swyer \& Emmens ${ }^{2}$ ) have already reported in detail the viscometric determination of hyaluronidase activity.

As natural chitin is insoluble in water, it can not be used for the viscometric assay. The determination of chitinase activity by viscometric technique has been reported by Tracey ${ }^{3}$, using the solution of chitosan acetate, prepared by the partial deacetylation of chitin, as the substrate. Hultin ${ }^{4)}$ has prepared carb-

\footnotetext{
* Ujina-chô, Hiroshima City, Japan.

1) D. McClean and C.W. Hale, Biochem. J., 35, 159 (1941).

2) G.I.M. Swyer and G.W. Emmens, Biochem. J., 41, 29 (1947).

3) M.V. Tracey, Biochem. J., 61, 579 (1955).

4) E. Hultin, Acta Chim. Scand., 9192 (1955).
}

oxymethyl chitin from regenerated chitin and reported it to be useful as a stable substrate. However, both the materials have two disadvantages that the viscosity is remarkably affected by added salts or $\mathrm{pH}$, and chemical depolymerization or deacetylation probably occurs in the course of preparation.

Senju and Okimasu ${ }^{5,6)}$ have prepared a new water soluble derivative by glycolating chitin with ethylene oxide, which is hardly depolymerized and deacetylated. Okimasu and ōta$k^{2} a^{7)}$ have previously reported that exocellular chitinase of black-koji molds splits glycol chitin, resulting in a rapid reduction of viscosity and in the production of reducing sugar. Accordingly, it is supposed that the glycol chitin can be used as more suitable substrate than other derivatives formerly used. In the present paper, the viscometric determination of chitinase activity carried out using glycol chitin as the substrate has been reported.

\footnotetext{
5) R. Senju and S. Okimasu, J. Agr. Chem. Soc. Japan, 23, 432 (1950).

6) S. Okimasu and R. Senju, ibid., 23, 437 (1950).

7) S. Okimasu and A. Ôtakara, J. Agr. ibid., Japan, 34,8 73 (1960).
} 


\section{EXPERIMENTAL}

\section{Preparation of Glycol Chitin}

Chitin was isolated from crust shell of crab by an usual method. However, the isolation was carried out avoiding a drastic treatment which possibly cause depolymerization or deacetylation. Therefore, the material made free from calcium carbonate was extracted several times with $2 \mathrm{~N}$-sodium hydroxide solution for $1 \sim 2$ hours at $70 \sim 80^{\circ} \mathrm{C}$, but the bleaching with permanganate solution was omitted. The glycolation of chitin with ethylene oxide was carried out by the method of Senju and Okimasu ${ }^{5)}$. Namely, alkali chitin was dispersed in $13 \%$ sodium hydroxide solution in a final concentration with ice at $0^{\circ} \mathrm{C}$, and then the dispersed solution was kept for three hours at $30^{\circ} \mathrm{C}$, after the addition of 1.5 times of weight of ethylene oxide to the amount of chitin used. Glycol chitin was precipitated and completely washed with $90 \%$ alcohol. Purification was attained by reprecipitating it with the addition of alcohol from the swollen mass, which dispersed the precipitate in a small volume of water, and subsequently it was washed with absolute alcohol and ether. The degree of polymerization was proved to be about 820 by the viscomertic method ${ }^{6)}$. Found: $\mathrm{N}, 5.60 ; \mathrm{CH}_{3} \mathrm{CO}, 16.41 \%$. Calcd. for monohydroxyethyl chitin: N, 5.67; $\mathrm{CH}_{3} \mathrm{CO}, 17.41 \%$.

\section{Enzyme Solution ${ }^{8)}$}

The water extract of wheat-bran culture of blackkoji mold (Aspergillus niger $\mathrm{K}_{14}$ ) and its purified enzyme preparation were used. The optimum $\mathrm{pH}$ showed 3.6.

\section{Viscometric Assay}

Substrate Solution: Stock solution was prepared by dissolving $5 \mathrm{~g}$ of glycol chitin in 11 of distilled water and subsequently removing a small insoluble material by centrifugation and filteration. This solution was stored in refrigerator under the addition of toluene without reduction of viscosity for several months or more. The concentration of substrate solution was estimated by weighing its dry material. The substrate solution for viscometric assay was daily prepared by diluting the stock solution.

Procedure: Five $\mathrm{ml}$ of glycol chitin solution was well mixed with $4 \mathrm{ml}$ of Mcllvaine buffer solution in Ostwlad's viscosimeter (The flow time of water is 42.3 seconds). After ten minutes incubation at $30^{\circ} \mathrm{C}$, one milli-liter of enzyme solution, diluted properly and

\footnotetext{
8) A. Ôtakara, This Journal, 25, 54 (1961).
}

preincubated at the same temperature, was added and rapidly mixed. Flow time was measured frequently at definite intervals. On the blank test, distilled water was added to a substrate buffer mixture in place of the enzyme solution. The activity was determined on the basis of the amount of enzyme, required to halve the viscosity increment (relative viscosity-1) in the arbitrary reaction time, as described in the following results.

\section{RESULTS AND DISCUSSION}

\section{Effect of pH and Added Sodium Chloride on the Viscosity of Substrate Solution}

As shown in Fig. 1, no remarkable change in the viscosity of buffered substrate solution was observed over the range of $\mathrm{pH} 3 \sim 7$. The effect of increasing concentration of sodium chloride was shown in Fig. 2, where the viscosity was almost unchanged, even though sodium chloride solution was added amounting to a final concentration of $0.5 \mathrm{M}$. In the

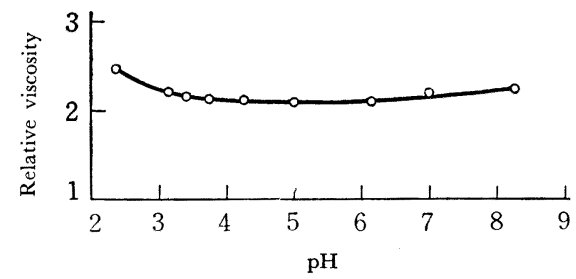

FIG. 1. Effect of $\mathrm{pH}$ on the Viscosity of Glycol Chitin Solution

Reaction mixture is composed of $5 \mathrm{ml}$ of $0.2 \%$ glycol chitin solution, $4 \mathrm{ml}$ of McIlvaine buffer solution of various $\mathrm{pH}$ and $1 \mathrm{ml}$ of distilled water. Temperature; $30^{\circ} \mathrm{C}$.

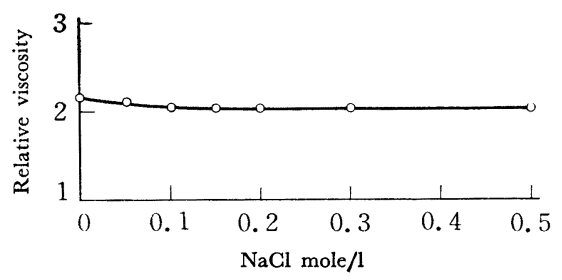

FIG. 2. Effect of Added Sodium Chloride on the Viscosity of Glycol Chitin Solution

Reaction mixture is composed of $5 \mathrm{ml}$ of $0.2 \%$ glycol chitin solution, $4 \mathrm{ml}$ of McIlvaine buffer solution ( $\mathrm{pH} \mathrm{3.6)}$ and $1 \mathrm{ml}$ of various concentration of sodium chloride solution. Temperature; $30^{\circ} \mathrm{C}$. 
absence of enzyme solution, the viscosity of reaction mixture did not change at all under the condition required to determine the chitinase activity. These stability of the substrate solution finely agrees with the fact that glycol chitin is a non-electrolytic macromolecular compound, and that the substrate used on this experiment is actually deacetylated by only about $6 \%$. Therefore, in the case of glycol chitin, it is not necessary that the ionic strength of the reaction mixture should be kept constant as in the case of chitosan acetate and carboxymethyl chitin. Thus, it is concluded that the glycol chitin is suitable as the substrate for the viscometric determination of chitinase activity.

Relationship of Viscosity Reduction of Substrate Solution to Enzyme Concentration

Mold enzyme caused a rapid reduction in the viscosity of substrate solution as shown in Fig. 3. These curves show the typical ones of viscosity reduction plotted against reaction

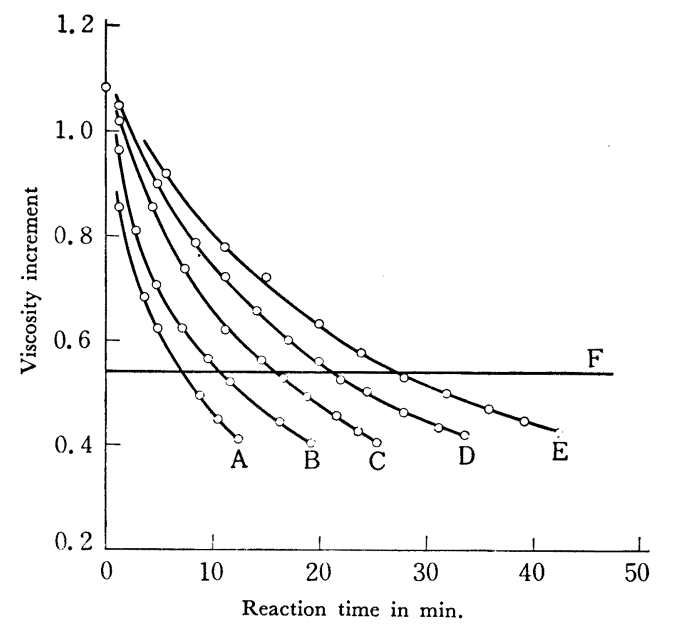

FIG. 3. Viscosity Reduction of Glycol Chitin Solution by Various Concentration of Enzyme Solution

The reaction was carried out in $0.1 \%$ final concentration of glycol chitin at $30^{\circ} \mathrm{C}$ under $\mathrm{pH}$ 3.6. Purified enzyme solution from black-koji mold was used : A, 1/100 dilution of the enzyme solution; $\mathrm{B}, 1 / 150 ; \mathrm{C}, 1 / 200 ; \mathrm{D}, 1 / 300 ; \mathrm{E}, 1 / 400$. F indicates the half viscosity increment line.

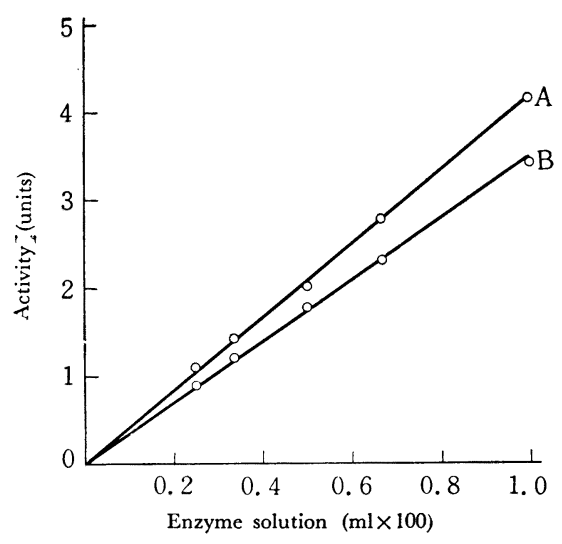

FIG. 4. Relationship between Activity and Enzyme Concentration

A; $0.1 \%$ final concentration of glycol chitin B; $0.2 \%$

time. "Half-life time", the time which required to halve the viscosity increment, can be obtained from each of the points which these curves intersect the half viscosity increment line ( $\mathrm{F}$ in Fig. 3), and it was inversely proportional to enzyme concentration. Therefore, if the amount of enzyme required to reach half-life time in thirty minutes is taken as one unit of viscometric activity, it is confirmed that the activity is proportional to the amount of enzyme used, as shown in Fig. 4.

On the other hand, Elson-Morgan and Morgan-Elson reaction's test of the reacting mixture were negative on each of the experiments. Therefore, it is clear that no amino sugar is liberated during the determination of viscometric activity.

Effect of Substrate Concentration and Different Preparation of Substrate on the Activity

The experiment, carried out in $0.2 \%$ final concentration of glycol chitin under the same condition, gave similar curves to those in Fig. 3, then, half-life time was known in the same manner and consequently the proportional relationship between the activity and the amount of enzyme used was ascertained. 
However, the activity appeared somewhat lower in high concentration of the substrate than in low one (Fig. 4). The effect of substrate concentration on the activity was then examined. As shown in Fig. 5, the activity was not completely independent of the concentration of substrate solution, but it became progressively and proportionally low as the latter was increased. Accordingly, on the determination of activity, attention should be given to substrate concentration. When the experiment was carried out in $0.1 \%$ final concentration of glycol chitin, the relative viscosity of blank test appeared within the range of 2.0 2.1 on daily assay. Judging from the relationship between the relative viscosity of different concentration of substrate solution and the activity determined, as presented in Table I, it is apparent that such a little difference of relative viscosity do not afford a significant error to the activity value.

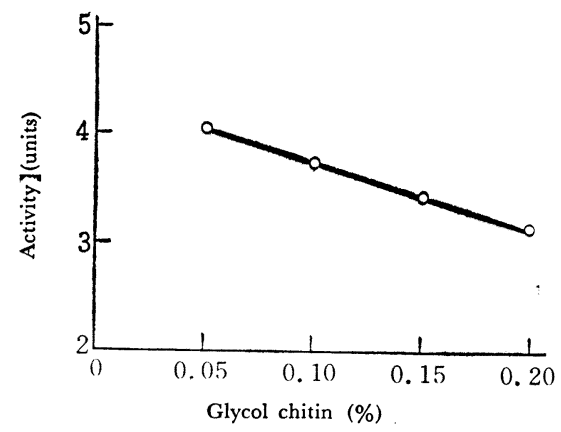

FIG. 5. Effect of Substrate Concentration on the Activity

Table I. Relative Viscosity of Substrate SOlution AND ACTIVITy VALUE

$\begin{array}{ccc}\begin{array}{c}\text { Glycol chitin } \\ \text { concentration }\end{array} & \begin{array}{c}\text { Relative } \\ \text { viscosity }\end{array} & \begin{array}{c}\text { Ratio of } \\ \text { sctivity }\end{array} \\ 0.05 & 1.501 & 108 \\ 0.10 & 2.040 & 100 \\ 0.15 & 2.636 & 90 \\ 0.20 & 3.578 & 83\end{array}$

Relative viscosity was measured at $30^{\circ} \mathrm{C}$ in the reaction mixture containing Mcllvaine buffer solution of $\mathrm{pH}$ 3.6.
TABle II. Determination of the ACtivity USING SUBSTRATES FROM DIFFERENT PREPARATION

$\begin{array}{ccccc}\begin{array}{c}\text { Prepara- } \\ \text { tion }\end{array} & \begin{array}{c}\text { Degree of } \\ \text { polymeri- } \\ \text { zation }\end{array} & \begin{array}{c}\text { Glycol chitin } \\ \text { concentration } \\ \%\end{array} & \begin{array}{c}\text { Relative } \\ \text { viscosity }\end{array} & \begin{array}{c}\text { Ratio of } \\ \text { activity }\end{array} \\ \text { No. } 1 & 820 & 0.10 & 2.068 & 100 \\ \text { No. } 2 & 798 & 0.10 & 2.059 & 78 \\ \text { No. } 3 & 694 & 0.12 & 2.090 & 55\end{array}$

Each of the substrate solution was prepared so as to have the relative viscosity ranging from 2.0 to 2.1 . Glycolation was carried out by the same method as described in the procedure using different source of chitin. Chitin used in No. 3 was isolated by boiling for one hour with $20 \%$ sodium hydroxide solution, bleaching with permanganate solution and subsequently decolorizing with sodium sulfite solution.

When the substrate derived from different preparation were used for viscometric assay, differences were found among the activities determined at the same enzyme solution, as presented in Table II. Though this phenomenon was frequently observed on the determination of other mucopolysaccharase activity, such defect could not be excluded also in the case of this substrate. Namely, being used the substrate solution which gives low viscosity due to partial depolymerization, the activity results in low value. Accordingly, the activities determined using different source of substrates need appropriate conversion among them, but it is desirable that the activity on the same experiment is determined using the same preparation of substrate.

Viscometric Determination of Chitinase Activity

From the results obtained above, the viscometric determination of chitinase activity is carried out in the following manner.

1) Glycol chitin solution is used in the final concentration of $0.1 \%$. For practical purposes, it is sufficient that the substrate solution is prepared so as to have the relative viscosity ranging from 2.0 to 2.1 .

2) The activity is determined on three different concentrations of unknown enzyme solution and the average is taken. It is proper that enzyme solution is diluted to reach half- 
life time within ten to twenty minutes.

3) Viscosity reduction of the reaction mixture is measured under the optimum $\mathrm{pH}$ of enzyme at $30^{\circ} \mathrm{C}$ and the time required to reach half-life time is obtained.

4) One unit of chitinase activity is expressed in terms of the amount of enzyme required to reach half-life time in thirty minutes. Therefore, chitinase unit is calculated as follows: unit $=30 /$ time (min.) required to reach half-life time $x$ dilution of enzyme solution

Acknowledgements The author wishes to express his sincere thanks to Prof. Y. Ōshima of Kyūshū University for his encouragement and his interest in this work, and also to Dr. S. Okimasu of this college for his kind advice and discussion.

[Agr. Biol. Chem., Vol. 25, No. 1, p. 54 60, 1961]

\title{
Studies on the Chitinolytic Enzymes of Black-koji Mold
}

\author{
Part II. Purification of Chitinase
}

\author{
By Akira ŌTAKARA \\ Hiroshima Women's Jr. College*
}

Received July 26, 1960

\begin{abstract}
Purification of chitinase was carried out from wheat-bran culture of black-koji mold, employing fractionation by ammonium sulfate, adsorption on calcium phosphate gel and column chromatography by hydroxylapatite. The enzyme preparation was obtained in a highly purified state and had a powerful property of decreasing the viscosity of glycol chitin solution, being accompanied wtih depolymerization of substrate molecule.
\end{abstract}

The presence of chitinase has hitherto been extensively investigated by many workers on the following various sources: the digestive fluid of snails, the exuvial fluid of silkworms, insects larvae, earthworms, termites, almonds, and a variety of bacteria and molds. In earlier times, Zechmeister et al.1,2) have demonstrated that chitinase can be separated

* Ujina-cho, Hiroshima City, Japan.

1) L. Zechmeister, G. Tóth and M. Bálint, Enzymologia, 5, 302 (1938).

2) L. Zechmeister and G. Tóth, Enzymologia, 7, 165 (1939). from almond emulsin using a column of bauxite. However, the purification has scarcely been studied, until reported by several workers past five years. Jeuniaux ${ }^{3 \sim 6)}$ has obtained chitinase in a purified state from cultural filterate of Streptomyces $s p$. and reported it to be free from cellulase activity. The purification has also been carried out by Berger

\footnotetext{
3) C. Jeuniaux, Arch. intern. Physiol. Biochim., 64, 522 (1956).

4) C. Jeuniaux, ibid., 65, 135 (1957)

5) C. Jeuniaux, Biochem. J., 66, 29P (1957).

6) C. Jeuniaux, Arch. intern. Physiol. Biochim., 67, 597 (1959).
} 